\title{
Reproductive characteristics of the polymorphic Caribbean reef building coral Montastrea annularis. III. Reproduction in damaged and regenerating colonies
}

\author{
Manfred L. J. Van Veghel ${ }^{1,2}$, Rolf P. M. Bak ${ }^{2,3}$

\begin{abstract}
${ }^{1}$ CARMABI Foundation - Ecological Institute Institute, PO Box 2090, Curaçao, Netherlands Antilles ${ }^{2}$ University of Amsterdam, Institute of Taxonomic Zoology, PO Box 4766, 1009 AT Amsterdam, The Netherlands ${ }^{3}$ Netherlands Institute for Sea Research (NIOZ), PO Box 59, 1790 AB Den Burg, Texel, The Netherlands
\end{abstract}

\begin{abstract}
We studied the relation between surface lesion regeneration and reproduction in distinct morphotypes of the coral Montastrea annularis (Ellis \& Solander). There were significant differences between the morphotypes (viz. 'Bumpy', 'Massive' and 'Columnar'; Van Veghel \& Bak 1993, Mar. Ecol. Prog. Ser. 92: 255-265). The number of eggs per gonad in polyps adjacent to the lesions was reduced in the Massive and Bumpy morphs but not in the Columnar morph. Fecundity (eggs per polyp) and the number of gonads per polyp were reduced in these areas in all morphs. We found a significantly higher regeneration rate for the Bumpy compared with the other 2 morphotypes. Regeneration rates were similar in the Columnar and Massive morphotypes. Regeneration rates in this study were relatively low, suggesting that regeneration is slower during the reproductive season.
\end{abstract}

KEY WORDS: Reproduction $\cdot$ Regeneration $\cdot$ Corals $\cdot$ Caribbean $\cdot$ Montastrea annularis $\cdot$ Polymorphism

\section{INTRODUCTION}

Partial mortality in large massive corals, rather than whole colony mortality, has been described as the major contributor to the loss of living tissue by coral populations (Hughes \& Jackson 1985). The increase of human activity on coral reefs during the last decades, e.g. anchoring and scuba diving, has probably increased events of partial mortality. Corals are able to repair small lesions; however, damage probably has energetic consequences for other life history aspects.

Regeneration characteristics have been studied for several coral species and were found to be different between species (Bak et al. 1977, Bak \& Steward van Es 1980, Meesters et al. 1992). There is also proof that life history attributes such as growth, competitive ability, survival and reproduction were affected during tissue regeneration (Loya 1976, Bak et al. 1977, Bak \& Steward van Es 1980, Bak 1983, Meesters et al. 1992, Meesters \& Bak 1993).
Recent studies on intermorphic variation in a prominent Caribbean reef building coral, Montastrea annularis (Ellis \& Solander), have shown significant differences in life history characteristics of 3 sympatric morphotypes: viz. 'Bumpy', 'Massive' and 'Columnar' (Tomascik 1990, Knowlton et al. 1992, Van Veghel \& Bak 1993, Weil \& Knowlton 1994). In addition to other reproductive characteristics of these morphotypes such as gametogenesis and spawning behavior (Van Veghel 1994), fecundity, and colony structure (Van Veghel \& Kahmann 1994), the impact of injuries on reproduction in the $3 \mathrm{M}$. annularis morphotypes was examined in this study.

We made superficial lesions on the surfaces of colonies of the 3 morphotypes about $10 \mathrm{wk}$ before spawning. Subsequently the regeneration of the lesions was followed. Montastrea annularis is a hermaphroditic broadcast spawner and a few days before spawning coral tissue was sampled to examine the fecundity of the experimental colonies. Conse- 
quently the effect of regeneration on reproduction as well as the regeneration capacity of the different morphotypes were determined.

\section{MATERIALS AND METHODS}

Lesions. Lesions were made on the upper surface of haphazardly selected colonies of the 3 Montastrea annularis morphotypes ( $\mathrm{n}=25$ colonies of each morph). Each lesion consisted of a superficial wound where tissue and skeleton were removed. The lesions were inflicted using a submersible drill powered by compressed air and equipped with a small grinding point, diameter $10 \mathrm{~mm}$ (Meesters \& Bak 1993). Lesion size (mean $\pm \mathrm{SD}$ ) was $160( \pm 20) \mathrm{mm}^{2}$; and lesion depth (mean $\pm \mathrm{SD}$ ) was $4( \pm 0.8) \mathrm{mm}$.

Lesions were made on 13 and 14 July 1992, about 10 wk before Montastrea annularis colonies were observed spawning on 17 to 19 September 1992 (Van Veghel 1994). The experiments were carried out in situ on the reefs near CARMABI Buoy 1, on the leeward coast of Curaçao, at a depth between 11 to $16 \mathrm{~m}$. For descriptions of the study reef, see Bak (1977), Van Duyl (1985) and Van Veghel (1994).

Regeneration. Regeneration rates were measured as decreasing lesion areas, using a plexiglass ruler (Meesters \& Bak 1993; Fig. 1). Experimental colonies were examined 4 times in the first week of study, weekly during the following $13 \mathrm{wk}$ and then biweekly to complete a $23 \mathrm{wk}$ period. Mean regeneration rates were calculated for each experimental colony with regression analysis, and values for slope and constant in the regression equation were calculated for each morphotype (Fig. 2; Table 1).

Reproduction. About 3 d before spawning, 10 experimental colonies per morphotype were sampled for 3 categories of coral tissue: (1) regenerated tissue $(<2 \mathrm{~cm})$, (2) living tissue adjacent to lesion, (3) living tissue $\gg 20 \mathrm{~cm}$ from lesion. Samples were processed and examined as described by Van Veghel \& Kahmann (1994). Number of eggs per gonad and number of gonads per polyp were scored. For categories 2 and 3 an average of 250 and 100 polyps per morph were dissected, respectively. Few regenerated polyps (category 1) occurred but all were examined ( $\mathrm{n}<10$ ).

Statistics. Differences between regression slopes of regeneration rates of each morphotype were tested with a 1-way ANOVA. Homogeneity of variances was tested with Bartlett's test and was always non-significant, and data were normally distributed after logarithmic transformation (Kolmogorov-Smirnov test; Sokal \& Rohlf 1981). Differences in fecundity (eggs per polyp) of the dissected polyps (ca 20 polyps per sample) were tested with a 1-way ANOVA (Sokal \& Rohlf 1981).

\section{RESULTS}

Regeneration

During the first week after the initiation of the experiment, $86 \%$ of the lesions increased in size. This increase was possibly due to tissue die off at the damaged edge before the regeneration starts. After $14 \mathrm{~d}$ the damaged polyps at the periphery were regenerated in $99 \%$ of the lesions.

Regeneration rates were calculated from Day 7 , when maximum lesion size was reached, until: (1) lesion closed, (2) tissue was collected for dissection (Day 63), or (3) discontinuation of experiment after Day 161. Results for lesion size $(y)$ versus regeneration time in days $(x)$ are given in Table 1 . Regeneration was significantly faster in the Bumpy morphotype (ANOVA, $p<0.001)$. No differences were found between the other 2 morphotypes. Decrease of lesion size versus time is shown in Fig. 2. The first completely healed colony (Fig. 1) was observed on Days 49, 147 and 119 for Bumpy, Massive and Columnar, respectively.

\section{Reproduction}

No gonads were found in the few polyps that regenerated after the lesion infliction. In coral tissue around the lesions, both fecundity (eggs per polyp) and sexual activity (gonads per polyp) were significantly reduced (ANOVA, $\mathrm{p}<0.001$ ) compared to tissue from the same colony more than $20 \mathrm{~cm}$ distant from the lesion (Table 2). The Massive morphotype showed the largest decrease in fecundity, a reduction of $74 \%$, whereas the Bumpy and Columnar morphs were reduced to half the normal fecundity. Fertility ( $\%$ polyps with gonads) was reduced for all morphotypes, by amounts ranging

Table 1 Montastrea annularis. Regeneration rates in reproductive colonies. Equation: $Y=C \times 10^{A X} Y$ : lesion size; $C$ : constant; $A$ : average regression slope (standard error); $X$ : regeneration time (in days); ns: not significant; $r^{2}$ average explained variance. p: significance level of the associated 1-way ANOVA

\begin{tabular}{|c|c|c|c|c|}
\hline & $C$ & $A$ & $r^{2}$ & n \\
\hline Bumpy & 236 & $-0.016(0.009)$ & 0.82 & 25 \\
\hline Massive & 193 & $-0.008(0.003)$ & 0.82 & 25 \\
\hline Columnar & 185 & $-0.007(0.003)$ & 0.82 & 20 \\
\hline ANOVA & & $F$-value & $\mathrm{p}$ & $\mathrm{df}$ \\
\hline \multicolumn{2}{|c|}{ Bumpy-Massive } & 15.48 & $<0.001$ & 48 \\
\hline \multicolumn{2}{|c|}{ Bumpy-Columnar } & 15.95 & $<0.001$ & 43 \\
\hline \multicolumn{2}{|c|}{ Massive-Columnar } & 0.13 & ns & 43 \\
\hline
\end{tabular}



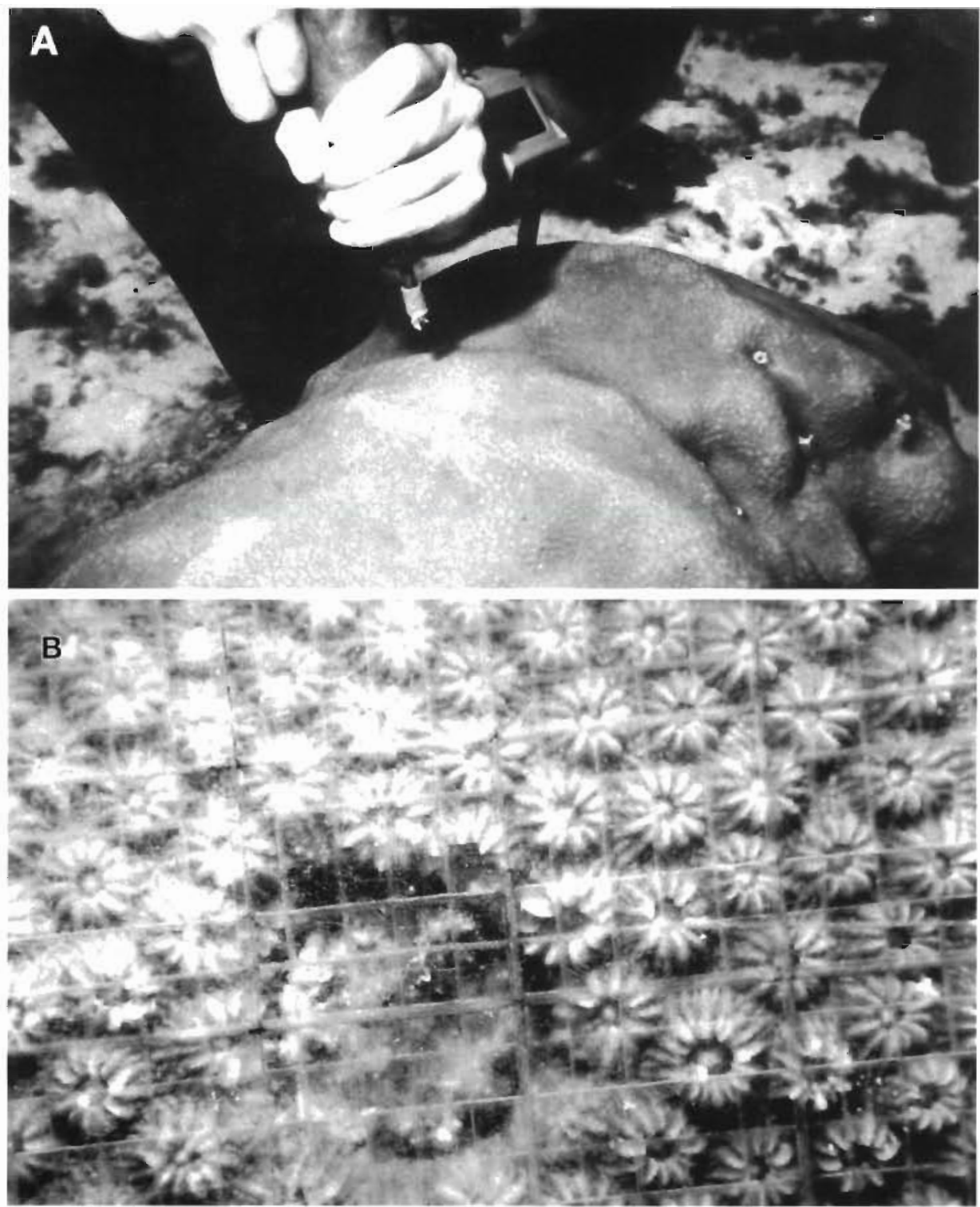

Fig. 1. Montastrea annularis Photographs showing the regeneration process. (A) Lesion just after infliction; (B) regenerating lesion of a Massive colony measured with a plexiglass ruler, $2 \times 2 \mathrm{~mm}$ squares ( $7 \mathrm{wk}$ after lesion infliction); (C) regenerated lesion of a Bumpy colony $(7 \mathrm{wk}$ after lesion infliction): note that pigmentation has not yet recovered

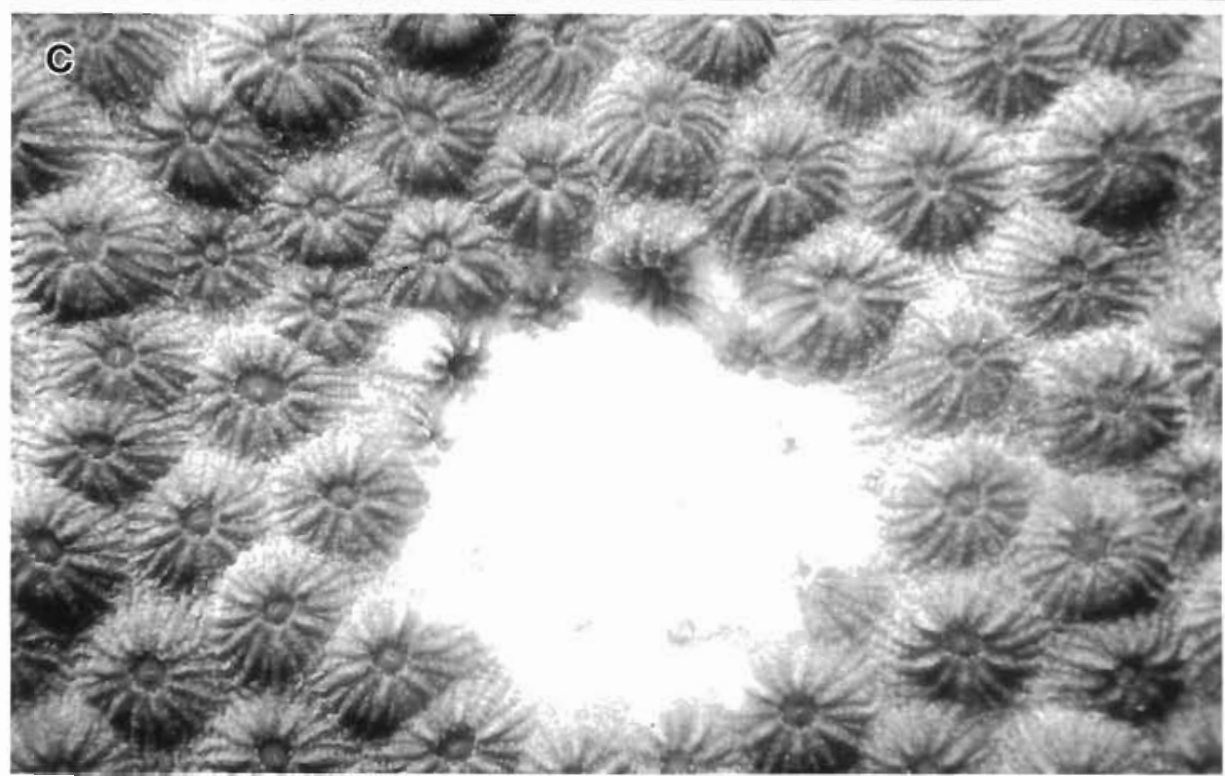



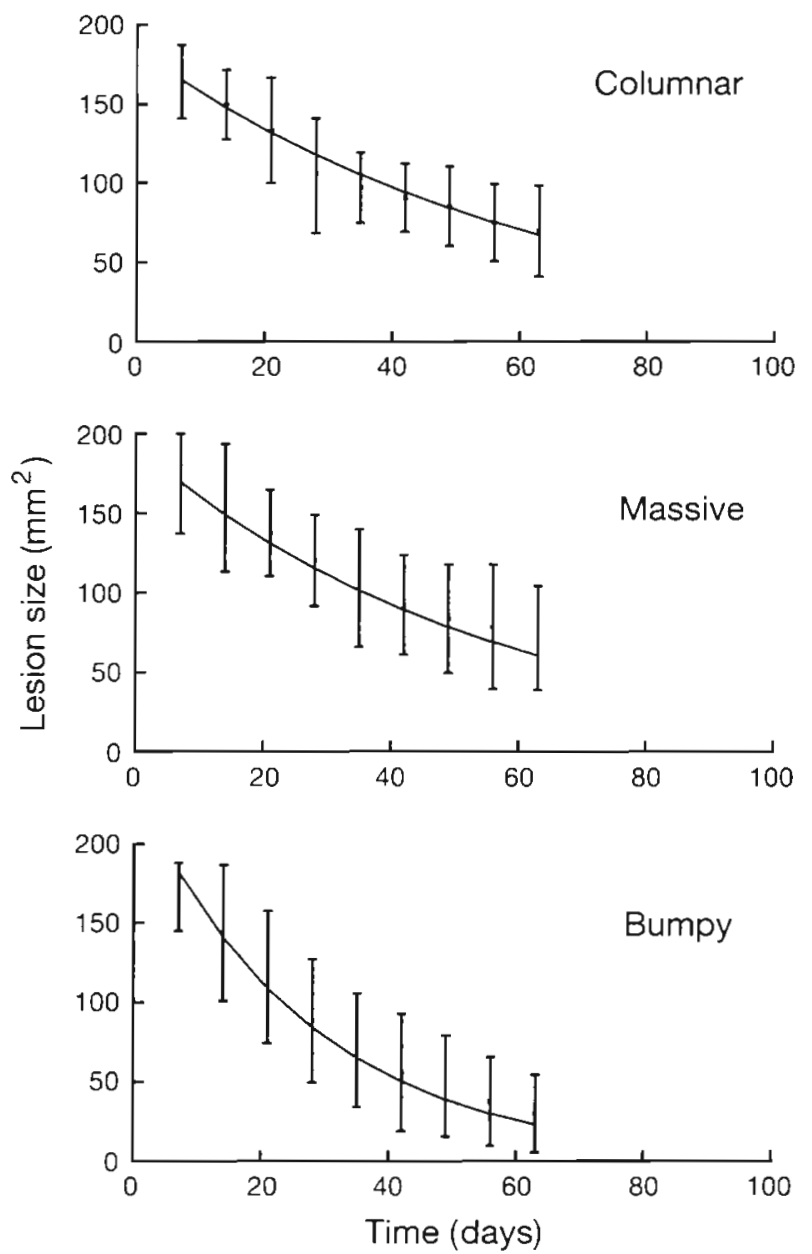

Fig. 2. Montastrea annularis. Calculated regression lines of regeneration rates in 3 morphotypes during the 1992 reproductive season. See Table 1 for regression equations, $\mathrm{r}^{2}$ and statistical analysis from $28 \%$ for Bumpy to $54 \%$ for Columnar. The latter did not show any differences in the number of eggs per gonad, whereas the Bumpy and Massive morphotypes showed a significant reduction (ANOVA, p $<0.001$ ). Dissected polyps near regenerating tissue often contained 2 different egg sizes, i.e. mature $(\approx 210 \mu \mathrm{m})$ and immature eggs $(\approx 140 \mu \mathrm{m})$.

\section{DISCUSSION}

The data show that lesion infliction and regeneration reduce fecundity in all 3 Montastrea annularis morphotypes, but also that there are differences between the morphs. Moreover, the processes of reproduction and regeneration appear to be linked.

Increase in lesion size during the first week of the study has been observed in regeneration experiments with other species (e.g. Bak \& Steward van Es 1980). This suggests that the regeneration process is not instant, but is held up by a delayed allocation of resources. In our study coral tissue adjacent to lesions often carnied both mature and immature eggs, such as occur in small immature colonies (Van Veghel \& Kahmann 1994). This may be a consequence of insufficient allocation of resources to reproductive tissue as a consequence of stress, e.g. the regeneration process, or a reduction in the quantity of living tissue. Such eggs could probably mature and be spawned during the second spawning episode of the split-spawning event (Van Veghel 1994).

The simultaneous reduction in fecundity and relatively low regeneration rates demonstrates the limited amount of energy available in coral energy budgets. Allocations to maintenance apparently limit reproduction, and vice versa. A similar phenomenon was

Table 2. Montastrea annularis. Fecundity (eggs per polyp) and aspects of reproductive effort for coral tissue adjacent to lesions and tissue $\gg 20 \mathrm{~cm}$ distant from lesion. One-way ANOVA $F$-values comparing differences between the regenerated and normal samples. $\cdots p<0.001$; ns: not significant; $n$ : number of dissected polyps; df; degrees of freedom

\begin{tabular}{|c|c|c|c|c|c|c|}
\hline & \multicolumn{3}{|c|}{ Regenerated } & \multicolumn{3}{|c|}{ Normal } \\
\hline & Bumpy & Massive & Columnar & Bumpy & Massive & Columnar \\
\hline Fecundity & $35.0(40)$ & $7.6 \quad(15)$ & $5.6(17)$ & $69.9(46)$ & $29.2(37)$ & 12.9 \\
\hline Gonads per polyp & $6.1(6.3)$ & $1.7(3.1)$ & $1.0(2.9)$ & $9.4(5.8)$ & $4.9(4.4)$ & $2.3(5.8)$ \\
\hline Eggs per gonad & $5.6(1.8)$ & $4.3(1.7)$ & $4.9(1.4)$ & $7.5(2.6)$ & $5.9(2.1)$ & $5.6(1.8)$ \\
\hline Fertility $(\%)$ & 57.6 & 31.1 & 15.3 & 80.0 & 49.0 & 33.0 \\
\hline $\mathrm{n}$ & 125 & 161 & 183 & 100 & 100 & 100 \\
\hline \multicolumn{7}{|l|}{ ANOVA F-value } \\
\hline & $\mathrm{df}$ & 223 & 259 & 281 & & \\
\hline Fecundity & $F$ & $37.0 \cdots$ & $42.9 \cdots$ & $7.9 \cdots$ & & \\
\hline Gonads per polyp & $F$ & $15.9^{\cdots} \cdots$ & $34.7 \cdots$ & $8.4^{\cdots}$ & & \\
\hline & $\mathrm{df}$ & 150 & 97 & 59 & & \\
\hline Eggs per gonad & $F$ & $39.5 \cdots$ & $16.1^{\cdots} \cdots$ & $0.3^{\mathrm{ns}}$ & & \\
\hline
\end{tabular}


demonstrated for Acropora palmata where regeneration suppressed linear growth (Bak 1983).

External factors have been reported to influence reproduction. A negative correlation between fecundity and other reproductive characteristics with depth, turbidity and sedimentation was described by Kojis \& Quinn (1984). In addition to such factors our data show the impact of factors such as partial mortality, directly affecting the coral's 'health'. Regeneration of broken branches in the coral species Stylophora pistillata (Esper) also resulted in a significant decrease of fecundity, lasting at least 19 mo after regeneration started (Rinkevich \& Loya 1989).

Regeneration rates and polyp regeneration were significantly higher for the Bumpy morphotype. The other 2 morphotypes did not differ in regeneration rate, confirming earlier data (Bak et al. 1977). This means that the Bumpy morphotype adds higher regeneration rates to its list of positive characteristics such as higher fecundity (Van Veghel \& Kahmann 1994) and successful intermorphic competition (Van Veghel \& Bak 1993).

Regeneration rates in this study are relatively low in comparison with other data using the same methods on comparable reefs of Curaçao, but outside of the reproductive season (Bak et al. 1977, Meesters et al. 1992, Meesters \& Bak 1993). Bak et al. (1977) observed the first colonies recovered from small (ca $1 \mathrm{~cm}$ diameter) lesions in Montastrea annularis after $11 \mathrm{~d}$. In comparison, the first recovered lesion in this study was found after $49 \mathrm{~d}$. Being reproductively active reduced the regeneration rate in $M$. annularis to about $23 \%$ and $32 \%$, for Columnar (Meesters et al. 1992) and Massive morphs (Meesters \& Bak 1993) respectively. Again we see the impact of external factors, such as bleaching and sedimentation, on an internal process reducing regeneration rate to about $48 \%$ (Massive morph; Meesters \& Bak 1993) and 33\% (Columnar morphi Meesters et al. 1992) of non-stressed rates, respectively.

During intensive sampling sessions (Van Veghel 1994, Van Veghel \& Kahmann 1994) larger lesions (about $20 \mathrm{~cm}^{2}$ ) were made. Most of these lesion regenerated and could barely be recognized $2 \mathrm{yr}$ after sampling took place, ergo no permanent damage was caused to the reef.

In conclusion, these data show that both reproduction and regeneration are linked life history processes, since there is mutual impact. There are significant differences within the Montastrea annularis morphotype complex with respect to life history aspects of regeneration and reproduction.

Acknowledgements. We thank the CARMABI Institute for providing research facilities. Erik Meesters and Jaap van der Meer and 2 anonymous reviewers suggested improvements to the manuscript. This research was funded by the Department of Biology of the University of Amsterdam.

\section{LITERATURE CITED}

Bak, R. P. M. (1977). Coral reefs and their zonation in the Netherlands Antilles. AAPG Stud. Geol. 4: 3-16

Bak, R. P. M. (1983). Neoplasia, regeneration and growth in the reef-building coral Acropora palmata. Mar. Biol. 77: 221-227

Bak, R. P. M., Brouns, J. J. W. M., Heys, F. M. L (1977). Regeneration and aspects of spatial competition in the scleractinian corals Agaricia agaricites and Montastrea annularis. Proc. 3rd int. coral Reef Symp., Miami: 143-148

Bak, R. P. M., Steward van Es, Y. (1980). Regeneration of superficial damage in the scleractinian corals Agaricia agaricites $\mathrm{f}$. purpurea and Porites astreoides. Bull. mar. Sci. 30: 883-887

Hughes, T. P., Jackson, J. C. B. (1985). Population dynamics and life histories of foliaceous corals. Ecol. Monogr. 55(2): $141-166$

Knowlton, N., Weil, E., Weigt, L. A., Guzmán, H. (1992). Sibling species in Montastrea annularis, coral bleaching. and the coral climate record. Science 255: 330-332

Kojis, B. L., Quinn, N. J. (1984). Seasonal and depth variation in fecundity of Acropora palifera at two reefs in Papua, New Guinea. Coral Reefs 3: 165-172

Loya, Y. (1976). Effects of water turbidity on the growth and sedimentation on the community structure of Puerto Rican reefs. Bull. mar. Sci. 26: 450-466

Meesters, E. H., Bos, A., Gast, G. J. (1992). Effects of sedimentation and lesion position on coral tissue regeneration. Proc. 7th int. coral Reef Symp., Guam (in press)

Meesters, E. H., Bak, R. P. M. (1993). Effects of coral bleaching on tissue regeneration potential and colony survival. Mar. Ecol. Prog. Ser. 96: 189-198

Rinkevich, B., Loya, Y. (1989). Reproduction in regenerating colonies of the coral Stylophora pistillata. In: Spanier, E. Steinberger, Y., Luria, H. (eds.) Environmental quality and ecosystem stability, Vol. IV, Environmental quality. ISEEQS Publ., Jerusalem, p. 257-265

Sokal, R. R., Rohlf, F. J. (1981). Biometry. W. H. Freeman and Co., New York

Tomascik, T. (1990). Growth rates of two morphotypes of Montastrea annularis along a eutrophication gradient, Barbados, W.I. Mar. Pollut. Bull. 21(8): 376-381

Van Duyl, F. C. (1985). Atlas of the living reef of Curaçao and Bonaire (Netherlands Antilles). Foundation for Scientific Research in Surinam and the Netherlands Antilles, Vol. 117, Utrecht, p. 37

Van Veghel, M. L. J. (1994). Reproductive characteristics of the polymorphic Caribbean reef building coral Montastrea annularis. I. Gametogenesis and spawning. Mar. Ecol. Prog. Ser. 109: 209-219

Van Veghel, M. L. J., Bak, R. P. M. (1993). Intraspecific variation of a dominant Caribbean reef building coral, Montastrea annularis: genetic, behavioral and morphometric aspects. Mar. Ecol. Prog. Ser. 92: 255-265

Van Veghel, M. L. J., Kahmann, M. E. H. (1994). Reproductive characteristics of the polymorphic Caribbean reef building coral Montastrea annularis. II. Fecundity and colony structure. Mar. Ecol. Prog. Ser. 109: 221-227

Weil, E., Knowlton, N. (1994). A multi-character analysis of the Caribbean coral Montastrea annularis (Ellis \& Solander, 1786) and its two sibling species, $M$. faveolata (Ellis \& Solander, 1786) and M. franksi (Gregory, 1895). Bull. mar. Sci. (in press)

Manuscript first received: August 18, 1993

Revised version accepted: March 30, 1994 